\title{
EFFECT OF PRODUCT PROMOTION, QUALITY PRODUCTS, CONSUMER SATISFACTION IN FORMING CONSUMER LOYALTY TO RETURN BUYING SAFETY SHOES PRODUCTS CV. BERKAH KARYA JAYA
}

\author{
Muhammad Noor Muhandisuddin NIM 17100101 \\ Postgraduate Magister Management Faculty of Economics \\ University of Muhammadiyah Gresik \\ Email : muhandisuddin@gmail.com
}

\begin{abstract}
CV. Berkah Karya Jaya is a company engaged in the production of safety shoes that have sold products in various provinces in Indonesia. In the last few months CV. Berkah Karya Jaya decreased sales turnover caused by marketing strategy factor, product quality and customer satisfaction factor. Customers in the purchase is influenced by several factors, among others, the cheap price, product quality and suitability between price and quality obtained which will affect the satisfaction of customers when using the product. Therefore the purpose of this research is the influence of promotion strategy, product quality and satisfaction to customer loyalty. The population in this study are all customers of safety shoes from CV. Berkah Karya Jaya. The sampling technique used is purposive sampling where the researcher determines the customer sample recorded in the CV. Berkah Karya Jaya based on the criteria that have been determined at least in the last year that is the number of 100 people.
\end{abstract}

The result of the research found that marketing strategy, quality and product satisfaction have significant effect either partially or simultaneously to customer loyalty CV. Berkah Karya Jaya. Product Promotion variables have a greater influence on customer loyalty than other variables that show regression coefficient value of 0.231 while the regression coefficient variable product quality and satisfaction each of 0.156 and 0.133 .

Keywords: product promotion, quality products, cunsomer satisfaction and cunsomer loyality

\section{PRELIMINARY}

The business world today is synonymous with business competition in which industry players face the challenge of getting their desired market share while consumers tend to be more sensitive to the value offered by each product. With the variety of products offered in the market, making consumers should be more selective in choosing a product with what brand is best able to meet their needs. So that consumers ultimately choose to consume a product not only based on its basic function (Primary Demand), but also the secondary function (secondary demand) ie the desire to consume a product with a certain brand that can meet the best needs (Radiosunu, 2005). 
Entrepreneurs are currently working hard to find the factors that influence consumers in choosing a product and devise appropriate marketing strategies, so as to win the existing business competition. The success of the company to establish relationships with consumers, so that it can survive in the long term and can maintain customer relationships on an ongoing basis is a competitive advantage for the company (Dharmmesta, 2007).

Maintaining good relationship between the seller and the consumer is indicated by the consumer's desire to make a repeat purchase of the product concerned, this indicates the existence of consumer confidence in the product which is influenced by several factors, namely the relatively cheap price, good product quality, and the appropriateness between the price and the quality obtained so that ultimately consumer satisfaction arises during the use of these products (Kotler, 2007).

One effort to recognize the state of consumers who are the target of sales is to learn how their behavior in buying a product. In general, before buying behavior occurs preceded by the interest or desire to buy that is driven by a certain motive that between individuals with each other can be different and influenced by many factors. According Rangkuti (2005), Consumers today will be more rational and more careful in purchasing a product and collect information first a product or goods to be purchased.

The problem of consumer loyalty is also experienced by CV. Berkah Karya Jaya is a business that produces and sells Safety Shoes products in East Java, Central Java, Yogyakarta and West Java. Results of sales of CV products. Berkah Karya Jaya is as follows:

\section{Table}

\section{Results of sales Safety Shoes products from CV. Berkah Karya Jaya}

\begin{tabular}{|c|c|c|c|c|}
\hline \multirow{2}{*}{ Territory } & \multicolumn{2}{|c|}{$\mathbf{2 0 1 5}$} & \multicolumn{2}{c|}{$\mathbf{2 0 1 6}$} \\
\cline { 2 - 5 } & Amount & \% & Amount & \% \\
\hline \hline Yogyakarta & 156.000 .000 & $17,72 \%$ & 182.750 .000 & $18,36 \%$ \\
\hline Central Java & 232.350 .000 & $26,39 \%$ & 260.250 .000 & $26,14 \%$ \\
\hline West Java & 234.750 .000 & $26,66 \%$ & 261.350 .000 & $26,25 \%$ \\
\hline East Java & 257.350 .000 & $29,23 \%$ & 291.200 .000 & $29,25 \%$ \\
\hline & $\mathbf{8 8 0 . 4 5 0 . 0 0 0}$ & $\mathbf{1 0 0 \%}$ & $\mathbf{9 9 5 . 5 5 0 . 0 0 0}$ & $\mathbf{1 0 0 \%}$ \\
\hline
\end{tabular}

Safety shoes (shoe shield) manufactured by CV. Berkah Karya Jaya is one of the Local Protective Equipment (APD) made locally (domestically) that has complied with Indonesian National Standard (SNI), and passed the test. Safety shoes shall be provided by the company for its workers to create Health and Safety (K3). As for Type of safety shoes (shoes protector) produced by CV. Berkah Karya Jaya is as follows:

1. Oil resistant, antiair, chemical resistant, heat resistant, steel sole

2. Oil resistant, water \& fat resistant

3. Oil resistant, antiair, chemical resistant, heat resistant

4. Oil resistant, acid resistant, chemical resistant, heat resistant

5. Oil resistant, antiair, acid resistant, chemical resistant, heat resistant, steel sole

6. Oil Resistant 
7. Safety shoes (shoes protector) for Women with oil resistant

In a few months in 2017 this CV. Berkah Karya Jaya experienced a decrease in sales turnover as shown in the table below:

\section{Table}

Financial Report on Sales Results During 2017

\begin{tabular}{|c|l|r|r|c|}
\hline No & Month & $\begin{array}{c}\text { Sales Value } \\
(\mathbf{R p})\end{array}$ & $\begin{array}{c}\text { Decrease Value } \\
(\mathbf{R p})\end{array}$ & $\begin{array}{c}\text { Decrease Percentage } \\
(\boldsymbol{\%})\end{array}$ \\
\hline \hline 1 & January & 87.850 .000 & 0 & 0 \\
\hline 2 & February & 85.500 .000 & -2.350 .000 & $-2,68 \%$ \\
\hline 3 & March & 83.350 .000 & -2.150 .000 & $-2,51 \%$ \\
\hline 4 & April & 82.675 .000 & -675.000 & $-0,81 \%$ \\
\hline 5 & May & 80.750 .000 & -1.925 .000 & $-2,33 \%$ \\
\hline 6 & June & 80.500 .000 & -250.000 & $-0,31 \%$ \\
\hline 7 & July & 79.950 .000 & -550.000 & $-0,68 \%$ \\
\hline 8 & August & 69.250 .000 & -10.700 .000 & $-13,38 \%$ \\
\hline 9 & September & 69.150 .000 & -100.000 & $-0,14 \%$ \\
\hline 10 & October & 68.890 .000 & -260.000 & $-0,38 \%$ \\
\hline
\end{tabular}

Based on the above data can be seen that there is a trend decline in sales turnover. Decrease in sales turnover is allegedly because there are various problems related to the marketing strategy in CV. Berkah Karya. The price of raw material of leather that continues to soar resulted in an increase in the selling price of safety shoes (protective boots) which ultimately impact on the decreasing purchasing power of the company. In addition, competition from similar goods producers capable of providing competitive prices and quality causes some companies to switch to ordering to other manufacturers. Similar companies that become competitors have the same marketing area as $\mathrm{CV}$. Berkah Karya Jaya. The products offered have the same quality, so that the presence of these competitors also influence the loyalty of consumers CV. Berkah Karya Jaya. Excess existing product safety shoes (shoes protector) CV. Berkah Karya Jaya is a stronger stitching quality and better quality of leather and iron materials and models that always match the market trend. The purpose of this study is to analyze the influence of promotion strategy, product quality and satisfaction to the loyalty of the product safety shoes (shoes protector) CV. Berkah Karya Jaya. 


\section{LITERATURE REVIEW}

\section{Consumer Loyalty}

According to Griffin (2005), Consumer loyalty is a buying behavior that can be defined as nonrandom purchases expressed over time by multiple decision-making units. Consumer loyalty is the willingness of consumers to continue to buy from a company in the long run and recommend products to friends and associates, including future preferences, wishes and intentions (Kottler and Keller, 2012). Consumer loyalty occurs when the consumer's assessment of the quality of a product or service is superior, the consumer's intentions will be favorable (ie, try to strengthen the relationship with a product, for example: state the positive about the product, remain loyal to the product, recommend the product to others. Increase the volume of purchase or willing to pay premium price. Behavioral intentions is what will signal whether consumers will remain loyal (loyal) or move (Rangkuti, 2010).

\section{Promotion}

Promotion is seen as a persuasive flow or one-way information that directs a person or organization to actions that create exchange in society. So promotion is an important aspect in marketing management and is often said to be a continuous process, because promotion can lead to a series of subsequent activities of the company (Private, 2004). In promoting the products and the company needs to do Strategy while the definition of strategy is a series of large designs that describe how a company should operate to achieve its goals.

\section{Product quality}

Product quality is the ability of a product to perform its functions, including in this case the overall reliability, reliability, accuracy, level of ease of operation, improvement and other attributes of value. Some quality experts define quality with varying interpretations (Kotler and Armstrong, 2006) Some of the results of the survey focused on the perception of the importance of the quality of products and services, including: public perceptions of the broader quality of products and services, increased views and role of top management, quality is not negotiable, quality includes everything ( quality is all-pervasive), quality improves productivity, quality affects better performance on the market, quality means improving business performance, high non-quality cost, consumer is king, quality is life view (Dale, 2003).

\section{Consumer satisfaction}

Basically understanding consumer satisfaction includes the difference between the level of importance and performance or perceived results. Engel (in Rangkuti, 2005) says that the understanding can be applied in the assessment of satisfaction or dissatisfaction with a particular company because both are closely related to the concept of customer satisfaction. 
According to Kotler (2007), Level of satisfaction is a function of the difference between perceived performance with expectations. In the context of consumer satisfaction, generally expectation is an estimate or consumer belief about what will be received. Their expectations are shaped by past purchasing experience, friends' comments and acquaintances and the promise of the company.

\section{Previous Research}

\section{Trisno Musanto (2004)}

a. Reliability has a significant effect on consumer loyalty.

b. Response to and remedy of problems positively affects consumer loyalty.

c. Sales experience positively affects consumer loyalty.

d. Convenience of acquisition has a positive effect on consumer loyalty

\section{Sunarto (2006)}

a. Brand reputation has a positive effect on consumer loyalty.

b. Customer satisfaction has a positive effect on consumer loyalty.

c. Service quality positively affects consumer loyalty.

\section{Andi Vita Sukmarini (2013)}

a. Promotion Strategy gives a positive and significant influence on consumer loyalty at PT. Toyota H. Kalla Makassar.

b. Product Quality (intervention / control variable) has an influence on consumer loyalty variable.

c. Sufficient level of satisfaction and desired level of satisfaction significantly and negatively affect consumer loyalty.

\section{CONCEPTUAL FRAMEWORK}

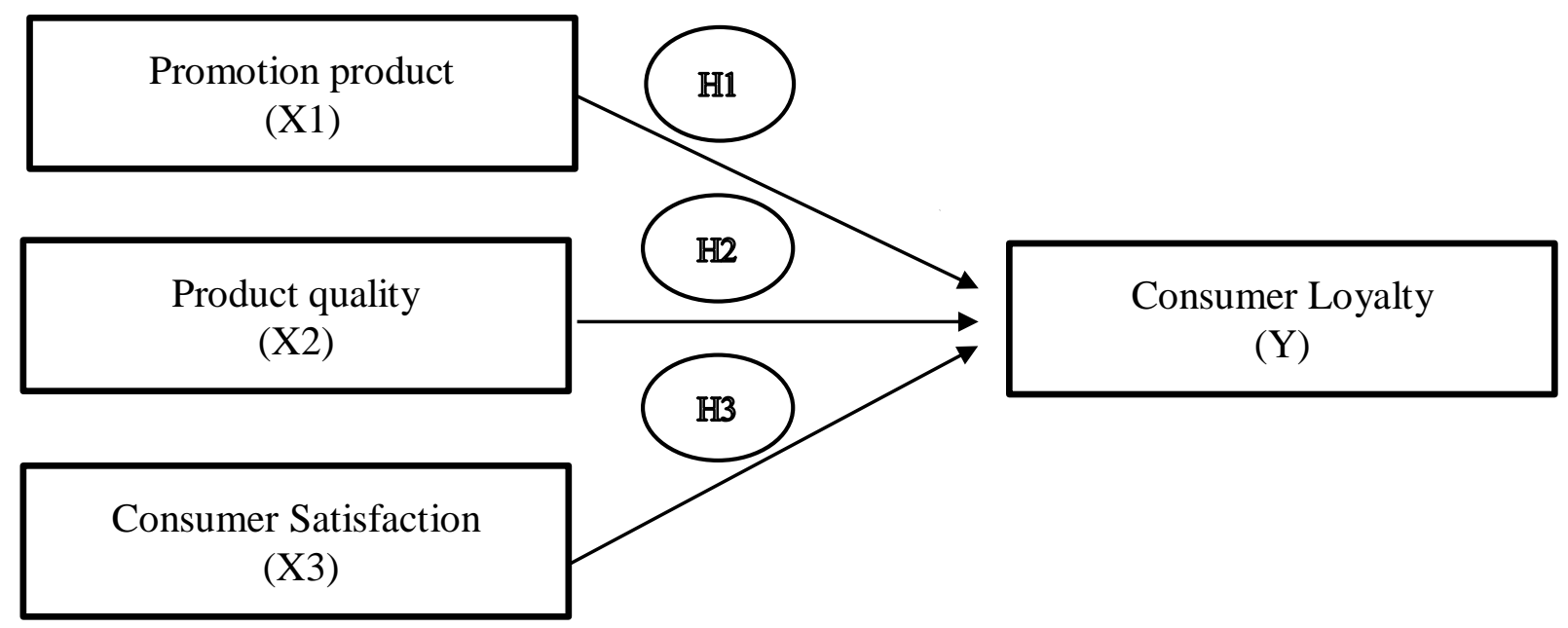




\section{HYPOTHESES:}

H1: Promotional variables affect the consumer loyalty safety shoes (shoes protector) product CV. Berkah Karya Jaya

$\mathrm{H} 2$ : Variable of product quality influence to consumer loyalty safety shoes (shoes protector) product CV. Berkah Karya Jaya

H3: The variable of customer satisfaction affect the consumer loyalty safety shoes (shoes protector) product CV. Berkah Karya Jaya.

\section{RESEARCH METHODS}

\section{Research variable}

1. Variable Consumer Loyalty

Loyalty can be interpreted as the power of the will of consumers to re-purchase products sold. This loyalty variable is measured using indicators of Cognitively Loyal, Affectively Loyal and Conatively Loyal.

\section{Product Promotion Variables}

Product promotion is a plan that indicates how managers allocate resources to individual products or product lines to achieve specific product goals. The promotion in this research is in the form of individual sales, calculated through target market targeting, contacting potential customers, making sales presentations, answering questions, closing sales and taking further action.

3. Product Quality Variables

Product quality is the consumer's assessment of the overall superiority of the product, or the expected superiority and control of the level of excellence to satisfy the consumer's wishes. The characteristics or dimensions of product quality are: performance, feature, reliability, conformance to specifications, durability, serviceability, estethic, and perceived quality.

\section{Consumer Satisfaction}

Consumer satisfaction is the feeling of pleasure or disappointment of a person as a result of a comparison between perceptions of the perceived and expected services. Indicators of consumer satisfaction are the needs and desires, past experiences, experiences of friends and communication through advertising and marketing.

\section{Sample Determination}

Population in this research is all consumer safety shoes (shoes protector) product CV. Berkah Karya Jaya. Sampling technique used is by purposive sampling where the researchers determine the samples of consumers recorded in the CV. Berkah Karya Jaya based on the criteria that researchers set that has been recorded at least for the past year.

\section{Types and Data Sources}

Primary data is data derived directly from data sources collected specifically and directly related to the problems studied. Primary data in this research is data obtained from respondents' answers to the series 
of questions used by researchers. While respondents who answered the questionnaire list is consumer safety shoes (shoes protector) product CV. Berkah Karya Jaya.

\section{Method of collecting data}

Data collection method used in this research is questionnaire method. The questionnaire method in its form bases itself on self-report (self report) or at least on personal knowledge and beliefs.

\section{Analysis Method}

Based on the relationship between two variables expressed by linear equations can be used to make predictions (predictions) about the value of $\mathrm{Y}$ (dependent variable) based on a certain $\mathrm{X}$ value (independent variable). Forecast (prediction) will be better if we not only pay attention to one variable that affects (independent variables) so using multiple linear regression analysis. The form of multiple linear regression equation used can be formulated: (Ghozali, 2006).

$$
\mathbf{Y} 1=\beta_{0}+\beta_{1} \mathbf{X}_{1}+\beta_{2} \mathbf{X}_{2}+\beta_{3} \mathbf{X}_{3}+\beta_{4} \mathbf{X}_{4}+\mathbf{e}
$$

Information :

Y: the dependent variable: Consumer Loyalty.

$\beta 0$ : coefficient of the constant.

$\beta 1$ : coefficient of independent variable quality of service

$\beta 2$ : coefficient of knowledge-free variable

$\beta 3$ : coefficient of independent variable of quality of satisfaction

$\mathrm{X} 1$ : free variable quality of service

X2: knowledge-free variable

X3: free variable satisfaction

e: intruder factor

\section{RESEARCH RESULT AND DISCUSSION}

Regression Result

\begin{tabular}{|c|c|c|c|c|c|c|}
\hline \multicolumn{7}{|c|}{ Coefficients } \\
\hline \multirow{2}{*}{\multicolumn{2}{|c|}{ Model }} & \multicolumn{2}{|c|}{$\begin{array}{l}\text { Unstandardized } \\
\text { Coefficients }\end{array}$} & \multirow{2}{*}{$\begin{array}{c}\begin{array}{c}\text { standardized } \\
\text { Coefficients }\end{array} \\
\text { Beta }\end{array}$} & \multirow[b]{2}{*}{$\mathrm{t}$} & \multirow[b]{2}{*}{ sig } \\
\hline & & $\mathrm{B}$ & Std. Error & & & \\
\hline \multirow{4}{*}{1} & (Constant) & -.851 & -.714 & & -1.187 & .231 \\
\hline & $\begin{array}{l}\text { Promotion } \\
\text { Strategy }\end{array}$ & .231 & .043 & .429 & 4.930 & .000 \\
\hline & $\begin{array}{l}\text { Product } \\
\text { quality }\end{array}$ & .156 & .040 & .319 & 3.587 & .001 \\
\hline & Satisfaction & .133 & .135 & .261 & 4.896 & .000 \\
\hline
\end{tabular}

a. Dependent Variable: Consumer Loyalty 
Based on the results of the calculation of multiple regression results can be made the following equation: $\mathbf{Y}=\mathbf{- 0 . 8 5 1}+\mathbf{0 . 2 3 1 X} 1+\mathbf{0 . 1 5 6} \times 2+\mathbf{0 . 1 3 3 X 3}$

The linear equation gives the following meanings:

a. Constanta $(\alpha)$ equal to $-0,851$, meaning if promotion strategy, product quality and satisfaction in permanent condition $(0)$ hence consumer loyalty still negative value.

b. The regression coefficient of promotion strategy $(\beta 1)=0,231$, it means that any improvement of promotion strategy will increase consumer loyalty.

c. Regression coefficient of product quality $(\beta 2)=0,156$, it means that every there is improvement of product quality hence will increase consumer loyalty.

d. The regression coefficient of satisfaction $(\beta 3)=0.133$, it means that any increase in satisfaction will increase consumer loyalty

TEST-F

ANOVA $^{\text {b }}$

\begin{tabular}{|c|l|r|r|r|r|r|}
\hline \multicolumn{2}{|c|}{ Model } & $\begin{array}{c}\text { Sum of } \\
\text { Squares }\end{array}$ & df & Mean Square & \multicolumn{1}{c|}{$\mathrm{F}$} & \multicolumn{1}{c|}{ Sig. } \\
\hline \multirow{3}{*}{1} & Regression & 148.546 & 2 & 49.511 & 111.351 & $.000 \mathrm{a}$ \\
\cline { 2 - 8 } & Residual & 42.684 & 91 & 440 & & \\
\cline { 2 - 8 } & Total & 191.235 & 99 & & & \\
\hline
\end{tabular}

a. Predictors: (Constant), Satisfaction, Promotion Strategy, Product Quality

b. Dependent Variable: Consumer Loyalty

Based on the F test results can be seen that the value of Fhitung equal to 111,351, with $\mathrm{p}$ value $<0,05$. Where the value of $p$ value obtained is 0.000 , because the value of $p$ value $<0.05$, it can be said that there is a significant influence simultaneously between promotion strategy variables (X1), product quality (X2) and Satisfaction (X3) to consumer Loyalty (Y)

Test-t

\section{Coefficients}

\begin{tabular}{|r|l|r|r|}
\hline \multicolumn{2}{|c|}{ Model } & $\begin{array}{r}\text { Sum of } \\
\text { Squares }\end{array}$ & \multicolumn{1}{c|}{ Sig. } \\
\hline \multirow{2}{*}{} & (Constant) & -1.187 & .231 \\
\cline { 2 - 4 } 1 & $\begin{array}{l}\text { Promotion } \\
\text { Strategy }\end{array}$ & 4.930 & .000 \\
\cline { 2 - 4 } & $\begin{array}{l}\text { Product } \\
\text { quality }\end{array}$ & 3.587 & .001 \\
\cline { 2 - 4 } & Satisfaction & 4.896 & .000 \\
\hline
\end{tabular}

a. Dependent Variable: Consumer Loyalty 
Based on the results of $\mathrm{t}$ test it can be done as follows:

1. T test result between promotion strategy to consumer loyalty 4,930 and sig. $0,000<0.05$. With these results then prove that the promotion strategy affects consumer loyalty.

2. The result of $t$ test between product quality to consumer loyalty is 3,587 and sig. $0.001<0.05$. With these results then prove that product quality affects consumer loyalty.

3. The result of $t$ test between satisfaction to consumer loyalty is 4,896 and sig. $0,000<0.05$. With these results then prove that satisfaction affects consumer loyalty.

Coefficient of determination

Model Summary

\begin{tabular}{|c|r|r|r|r|}
\hline Model & $\mathrm{R}$ & R Square & $\begin{array}{c}\text { Adjusted } \\
\text { R Square }\end{array}$ & $\begin{array}{c}\text { Std. Error of the } \\
\text { Estimate }\end{array}$ \\
\hline 1 & $.876^{\mathrm{a}}$ & .775 & .765 & .66680 \\
\hline
\end{tabular}

a. Predictors: (Constant), Satisfaction, Promotion Strategy, Product Quality

Coefficient of determination based on Adjusted R Square equal to 0,765 or 76,5\%. It can be interpreted that $76.5 \%$ customer loyalty CV. Berkah Karya Jaya on the research model is influenced by promotion strategy variables, product quality and satisfaction. While the remaining $23.5 \%(100 \%-76.5 \%)$ is influenced by variables other than promotion strategy, product quality and satisfaction such as price, distribution and others.

\section{Discussion}

1. The influence of promotion strategy on consumer loyalty

From the results of statistical tests of the first hypothesis shows the coefficient of promotion strategy has a significant number below $\alpha=0.05$ is 0.000 . The results of this study provide an explanation that the promotion strategy has a significant effect on customer loyalty $\mathrm{CV}$. Berkah Karya Jaya or in other words a good promotional strategy will give a positive influence on increasing consumer loyalty.

Promotion or marketing strategies have a significant effect on customer loyalty. A good marketing strategy that directly hit the consumer will encourage consumers to remain loyal to the same product (Andi Vita Sukmarini, 2013)

In the promotion strategy there is a combination of several elements of sales promotion, personal sales, public relations and publicity, and advertising. Promotion strategy applied in this research is in the form of individual sales because CV. Berkah Karya Jaya sales system is directly 
done by meeting direct consumers. Individual sales take a way from face-to-face or by phone and may be directed to the last intermediary or consumer.

2. Effect of product quality on consumer loyalty

The result of the statistical test on the second hypothesis shows that product quality variables have significant numbers below $\alpha=0.05$ ie 0.001 . The results of this study provide an explanation that the quality of the product have a positive and significant impact on consumer loyalty or in other words that with good product quality will encourage or give a positive effect on increasing consumer loyalty.

Product quality is the ability of a product to perform its functions, including in this case the overall reliability, reliability, thoroughness, level of ease of operation, improvement and other valuable attributes (Kotler and Armstrong, 2006). Product quality has a significant effect on consumer loyalty which covers aspects of durability, reliability, responsiveness, empathy and tangibles (Musanto, 2004).

3. The influence of satisfaction on consumer loyalty

The result of statistical test on the third hypothesis shows that the satisfaction variable has a significant number below $\alpha=0,05$ ie 0,000 . The results of this study provide an explanation that customer satisfaction has a positive and significant impact on customer loyalty CV. Berkah Karya Jaya or in other words that with high satisfaction will encourage or give a positive influence on increasing consumer loyalty.

According to Kotler (2007), Level of satisfaction is a function of the difference between perceived performance with expectations. In the context of customer satisfaction, generally expectations are consumer confidence about what will be received. Consumer expectations are influenced by their previous purchasing experience, the advice of friends and colleagues, as well as the promise and information of marketers and competitors and the expectations of these consumers from time to time evolved as the consumer experience progresses. Consumer satisfaction is a level where the needs, wishes and expectations of consumers can be met which will result in repeat purchase or continuing loyalty.

The result of determination coefficient test $(77,0 \%)$ shows that there is influence between promotion strategy variable, product quality and satisfaction toward customer loyalty CV. Berkah Karya Jaya, this indicates that the promotion strategy, product quality and satisfaction of consumer loyalty is an important factor that contribute to determine the high loyalty of consumer CV. Berkah Karya Jaya.

\section{CONCLUSION}

1. Promotion strategy has positive and significant impact to customer loyalty CV. Berkah Karya Jaya.

2. Product quality has positive and significant impact on customer loyalty CV. Berkah Karya Jaya.

3. Satisfaction has positive and significant impact on customer loyalty CV. Berkah Karya Jaya. 


\section{SUGGESTION}

1. Promotion strategy becomes the main variable affecting consumer loyalty. The lowest assessment by the respondents about the promotion strategy lies in the CV indicator. Berkah Karya Jaya is willing to give discounts to consumers. Therefore CV. Berkah Karya Jaya is expected to increase marketing strategy by enlarging discounts to consumers who make large purchases or to consumers who have high loyalty.

2. The variable of satisfaction becomes the second variable affecting consumer loyalty. The lowest assessment of satisfaction lies in the CV indicator. Berkah Karya Jaya offers its newest products with an attractive design, meaning that $\mathrm{CV}$. Berkah Karya Jaya needs to improve its product design as attractive as possible and follow fashion trends.

3. Product quality variables into variables that have the smallest influence on consumer loyalty. The lowest rating on product quality lies in the product indicator of CV. Berkah Karya Jaya is equipped with quality materials. Therefore CV. Berkah Karya Jaya needs to improve the quality of its products with better so that it can be a special attraction that makes consumers still willing to buy products from CV. Berkah Karya Jaya.

\section{Bibliography}

Andi Vita Sukmarini. 2013. Promotion Strategy Maintaining Consumer Loyalty of Toyota Brand Cars

PT. H. Kalla Makassar in Automotive Competition in Makassar. Faculty of Social Science and Political Science. Hasanuddin University

Arikunto, S. 2006. Research procedure: a practical approach. Revised Edition. Publisher Rineka Cipta. Jakarta

Cronin, JJ \& S.A. Taylor. 2002. Measuring service quality: a reexamination and extension. Journal of Marketing. Vol. 56.

Dale, Besterfield, 2003, Total Quality Management, Third Edition, Pearson, New Jersey.

Dharmmesta, Private Basu. 2007. Marketing management, consumer behavioral analysis. Yogyakarta: BPFE-Yogyakarta.

Ferdinand A, (2002). Structural Equation Modeling In Management Research. Issue 2, Series Key Library 03 / BP UNDIP

Ghozali, Imam. 2006. Application of Multivariate Analysis With SPSS Program. Agency Publisher UNDIP: Semarang

Griffin, Jill. 2005. Customer Loyalty, Growing and Maintaining Loyalty Consumer. Publisher: Erland, Jakarta

Husaini Usman, 2005. Introduction to Statistics. Earth Script. Jakarta

Kartajaya, H. 2007. Markplus on marketing: The second generation. Jakarta: Gramedia Pustaka.

Kotler and Keller, 2012. Marketing Management Issue 14, Global Edition.Pearson Prentice Hall.

Kotler, Philip, 2007, Marketing Management - Analysis, Planning, Implementation and Control, Volume 1 - 2, Indonesian Edition, Salemba Four, Jakarta.

Radiosunu. 2005. Marketing Management; An Analysis Approach, Second Edition, University Gajah Mada, Yogyakarta. 
Rangkuti, F. 2005. Customer satisfaction, measuring techniques and strategies to improve customer satisfaction plus case analysis of PLN-JP. Jakarta: Gramedia Pustaka Utama.

Rangkuti, F. 2010. Spiritual leadership in Bussiner. Wake up. Jakarta: Gramedia Pustaka Utama.

Samuel, Hatane and Foedjiawati. (2005). The Influence of Consumer Satisfaction Against Brand Loyalty (Case Study of The Prime Steak \& Ribs Surabaya Restaurant).

Storbacka, Strandvick and Gronross, 2004. Service management and marketing: a customer relationship management approach. 2nd edition. John Willey \& Sons. Ltd.

Sugiyono, 2007. Statistics for research. Jakarta: Alfabeta

Sunyoto, Danang. 2013. Research Methodology for Economics. CAPS, Yogyakarta

Sutantio, Magdalena. 2004. Study About Buying Interest in Extension Brand; Studies

Sharp Cases in Surabaya. Journal of Marketing Science Indonesia. Vol.III Swastha, Basu. 2004. Introduction to Modern Business. Jakarta: Salemba Four

Tjiptono, F. 2007. The principles of total quality. Andi Publisher. Yogyakarta. Usman, Husaini. 2005. Introduction to Statistics. Jakarta: Earth Literacy

Winarko, B., 2003, Era Customer Experience, Warta Ekonomi, Jakarta. 